\title{
Association between Degree of Leverages and Firm Value
}

\author{
Pradeep Kumar Gupta (Corresponding author) \\ L M Thapar School of Management \\ Thapar University Derabassi Campus \\ E-mails: pradeep.gupta@thapar.edu; gupta.pk1977@gmail.com
}

Shailendra Kumar

Indian Institute of Information Technology

Allahabad (U.P.), India

E-mails: shailendrak@iiita.ac.in; blyshailendra@gmail.com

PiyushVerma

L M Thapar School of Management

Thapar University Derabassi Campus

Derabassi, SAS Nagar (Punjab), India

E-mails: pverma@thapar.edu; piyushverma77@gmail.com

Received: April 5, 2016 Accepted: May 22, $2016 \quad$ Published: June 1, 2016

doi:10.5296/ajfa.v8i1.9455 URL: http://dx.doi.org/10.5296/ajfa.v8i1.9455

\begin{abstract}
This study aims to empirically investigate the association between degree of leverages, operating and financial, and firm value in the context of India, one of big ten emerging markets (Garten, 1997). This study examines this association for 231 manufacturing firms listed in National Stock Exchange (NSE) in India over a period from 2001-2002 to 2010-2011. The independent variables, degrees of operating and financial leverage, and a market price-based dependent variable, called price-earnings ratio as a proxy of firm value, are taken to examine this relationship by using standard ordinary least square regression
\end{abstract}


models at the levels of individual firm and portfolio of firms. The findings of this study show a statistically significant negative relationship between firm value and degree of operating leverage and a statistically insignificant relationship between firm value and degree of financial leverage both at the levels of individual firm and portfolio of firms. Using the data from a country like India, one of fastest growing emerging markets in the world, this study provides an important insight on the effect of leverages on the firm value, the association between independent accounting variables and stock price-based dependent variable, to the practitioners, the scholars and the finance managers.

Keywords: Portfolio; Operating Leverage, Financial Leverage, Price-earnings, Firm Value JEL Classification: G11; G30; G32 


\section{Introduction}

The appropriate and reliable accounting information in the financial statements are required by the active investors to analyze the economic performance and value of a firm. The usefulness of financial information to investors was assessed by the extensive studies on the value relevance of accounting data (Papadaki \& Siougle, 2007). Various empirical examinations and theoretical models have investigated the real determinants of stock price. Ball and Brown (1968) investigated the relationship between a stock price-based dependent variable and a set of accounting variables often viewed as Capital market-based accounting research (CMBAR). Habib (2004) investigates the quality of accounting information with respect to stock price. The financial reports are unable to fulfill one of their primary objectives if no association between accounting information and the market value of the company is found (Beisland, 2009). Therefore, there is always of great interest for the scholars and the practitioners to enquire about the impact of accounting numbers on the stock price and this relationship is extensively explored in the literature of value relevance research. An accounting number can be considered to be value relevant if it is helpful in explaining value or returns over long windows (Holthausen \& Watts, 2001). An accounting amount will be value relevant only if the amount reflects relevant and reliable information to investors in valuing the firms (Barth et al., 2001). Francis and Schipper (1999) reported that a statistical relationship between financial information and stock prices or returns is to be established for measuring the value relevance. There is a positive relationship between stock returns and debt to equity ratio of the firms (Bhandari, 1988). Thus, debt to equity ratio is considered to be value relevant. Dimitrov and Jain (2008) find that annual stock returns are significantly associated with contemporaneous changes in financial leverage and, hence, changes in financial leverage are value relevant. Habib and Azim (2008) find that firm-specific economic variables are important determinants of the value-relevance of accounting information. Thus, this study is an attempt to explore whether the market values the accounting numbers of the firms. This study takes two accounting variables, degrees of operating and financial leverage, to investigate their impact on value of the firm represented by one of the market-based performance indicators, called price-earnings (hereafter, PE) ratio. Moreover, the leverage becomes an important factor to design the structures of cost and capital to entail reducing the overall cost of operations including financing costs to attaining overall competitiveness by the firms operating in the manufacturing sector of India (Sharma, 2006) and it is also considered a leading factor to determine the firms' risk premium (Zimmer, 1990). A significant relationship between any fundamental variable and stock prices indicates that this fundamental variable is a value-relevant (Trabelsi, 2013) as its use may lead the value of firm close to its market value (Dumontier \& Raffournier, 2002).

The main objective of this study is to empirically investigate the combined effect of degrees of operating and financial leverage (hereafter, DOL and DFL) on the PE ratio, proxy for firm value, for 231 National Stock Exchange (NSE) listed manufacturing firms in India. Since much research studies in this topic have not been explored in the context of India, one of big 10 emerging markets (Garten, 1997) and listed as an emerging market by Dow Jones (2010), Economist (2009), FTSE (2010), MSCI (2010) and Hoskisson, et al. (2000) in the study of 
Merchant and Allen-Ford (2012, pp.369). Therefore, our study claims to questioning this relationship in the context of India. Two control variables, return on assets (Flatt \& Kowalczyk, 2008; Lee \& Swenson, 2012) and firm size measured as sales (Shehata, 1991) of the firms, that could affect firm value are also included in this study to determine the extent of their impact in explaining the firm value. The standard ordinary least square regression models at the levels of individual firm and portfolio of firms are performed to find the empirical results.

The rest of the paper is organized as follows. The next section is described related literature and hypotheses development. Section III explains the empirical test and design used in the paper. The results and analysis are taken in Section IV, and finally, Section V concludes.

\section{Literature Review and Hypothesis Development}

Over a period of five decades, empirical investigation of the relationship between leverage and firm value has always been of great interest for the scholars and practitioners around the world. In 1958 Modigliani and Miller found that the value of any firm does not depend on its capital structure in a perfect capital markets. In other words, the firm value is independent of its leverage. Sarma and Rao (1969) employed Merton H. Miller and Franco Modigliani's model to a non-regulated industry and tested the MM hypothesis on the influence of debt on the value of a firm and found the results in support of their hypothesis that "after allowing for the tax advantage from the interest paid on debt, the value of a firm is independent of its capital structure". However, we take both the leverages (operating and financial) to test our proposed hypotheses as only few studies have taken operating leverage as a determinant of firm value. Azmat (2014) investigate the relationship between firm value and cash holdings and find a concave relationship between firm value and cash holdings. The firms' value and financial leverage are significantly and directly associated (Sharma, 2006). Garcia and Jorgensen (2010) reported that a trade-off (Dotan \& Ravid, 1985; Trezevant, 1992) or a U-shaped relation (Huffman, 1983; Prezas, 1987; Kale, Noe, \& Ramirez, 1991) between operating and financial leverage exists due to the interactions between investment and financing decisions. The leverage causes a change in the volatility of stock returns (Christie, 1982; French, Schwert \& Stambaugh, 1987; Schwert, 1989; Cheung \& Ng, 1992 and Nishat, 2000).

Many empirical studies (Gahlon \& Gentry, 1982; Mandelker \& Rhee, 1984; Huffman, 1989; Carlson et al. 2004; Zhang, 2005; Cooper, 2006; Garcia \& Jorgensen, 2010) use DOL and DFL to test their respective hypotheses in the context of developed markets. We take DOL and DFL to empirically examine their impact on firm value in the context of India since the structures of business organizations in the emerging or developing markets are different from those in developed markets (Sarkar et al. 2008). Liquidity, taxation, stock market benchmarks, and different transactions and accounting methods are some of the parameters where international stock markets differ (Capital Markets in 2025, www.pwc.de). The process of integration of emerging markets into world markets is incomplete though correlations between developed and emerging markets have increased (Bekaert \& Harvey, 2013). Moreover, the replication of the depth of institutional liquidity, the kind of infrastructure and 
pools of human capital built by the developed markets organically is very difficult for emerging markets (International Equity Markets, www.bauer.uh.edu). Furthermore, emerging markets are heterogeneous in their level of development and environmental surroundings (Bianchi, 2014). Thus, 'developed' and 'emerging' markets are realistically different in many aspects including the structures of business organizations. An enormous scale of scholarly interest in emerging market phenomenon in management discipline is found in a casual review of academic literature on emerging markets (Merchant and Allen-Ford, 2012).

Mandelker and Rhee (1984) and Ang and Peterson (1984) were the pioneers to use the time-series regression method for estimating DOL and DFL. Several studies (e.g. Huffman, 1989; DeYoung \& Roland, 2001; Griffin \& Dugan, 2003; Ho, Xu, \& Yap, 2004; Garcia \& Jorgensen, 2010) used this method of estimation of DOL and DFL. However, a point-to-point method has also been used extensively in the literature for estimating DOL and DFL (Garcia \& Jorgensen, 2010). The point-to-point approach estimates DOL and DFL as net fixed assets to total assets ratio (Ferri \& Jones, 1979; Mandelker \& Rhee, 1984; Garcia \& Jorgensen, 2010) and total debt to total assets ratio (Mandelker \& Rhee, 1984; Garcia \& Jorgensen, 2010), respectively. Our study takes the point-to-point approach to measure DOL and DFL. Moreover, the study of Garcia and Jorgensen (2010) find similar results from both the approaches. When making equity valuation decisions investors consider firms' fundamentals as reflected in financial statements. However, which line item is more important for equity valuation is an important consideration (Habib, 2010). Cheng and Tzeng (2011) explored the impact of leverage on firm value and how does the firm financial quality influence this impact of leverage on firm value? They find the positive relationship between leverage and firm value when the firm financial quality is better. Kumar and Warne (2009) find two most significant parametric determinants, variability in market price and corporate size, of PE ratio in the context of Indian capital market. Anderson and Brooks (2006) find that the size of the firm, the year in which PE ratio is measured and the industry effect are the most influencing factors of firms' PE ratios. Sharma (2006) finds a significant correlation between firms' value and financial leverage. A significant portion of the variations in PE ratios is explained by the selection of firms based upon industry (Alford, 1992). PE ratio, first introduced in literature by Graham and Dodd (1934) as a benchmark for equity valuation, has the application based on the idea that earnings are related to value (Stefanis, 2005). There were of considerable interests to be known about the behaviour of PE ratio overtime and the relative importance of the factors influencing its behaviour (Beaver \& Morse, 1978). Our study takes book values of degrees of operating and financial leverage to investigate their influence over PE ratio to value the firms as there is a maintained popularity of using PE approach to security/equity valuation among practitioners and academics due to its simplicity (Pari, Carvell \& Sullivan, 1989; Lie \& Lie, 2002). An accurate measure of equity valuation is the PE ratio found in the study of Alford (1992). With these arguments, an alternative hypothesis of this study is proposed at firm level.

Hypothesis: At firm level, degrees of operating and financial leverage are associated with firm value (PE ratio). 
Other than the main interest variables (DOL and DFL), there are some other firm-level factors which could influence the firm value and these firm-level factors are to be controlled to improve the explanatory power of interest variables. An essential aspect of a research into a business activity must include the firm size (Zadeh \& Eskandari, 2012). Al-Khazali and Zoubi (2005) reported that accounting studies used size of the firms to explain differences across firms in their methods of accounting and decisions related to corporate disclosures (Jensen \& Meckling, 1978; Deakin, 1979, Collins, Rozeff \& Dhaliwal, 1981; Zmijewski \& Hagerman, 1981; Zimmerman, 1983; Hughes \& Ricks, 1984; and Shehata, 1991). For example, Shehata (1991) has used the total sales as firm size. Thus, it is important to include firm size as a control variable in the study. The firm size is measured as logarithm [1] of Sales. Moreover, this study also includes return on assets (ROA, hereafter) as a control variable (Lee and Swenson, 2012) which could impact the firm value. ROA is measured as Net operating profit after tax divided by Total assets. The study of Beaver et al. (1970) reports a widely thought evident fact that large firms have low variability of risk and asset returns than smaller firms in the literature. This means firm size and ROA should be included in the study for improving the explanatory power of DOL and DFL. Thus, the hypothesis proposed above is also examined the impact of DOL and DFL after controlling for firm size and ROA.

Mandelkar and Rhee (1984) found measurement errors of variables at the level of individual firm. Therefore, the portfolio-grouping procedures (Beaver et al. 1970; Black et al. 1972; Fama \& MacBeth, 1973) employed by Mandelkar and Rhee (1984) are used to reduce these measurement errors of variables. Under this approach, the average values of interest variables (PE, DOL and DFL) of total 231 sample firms are ranked in ascending order on the basis of beta values [2] of each firm's common stock and every three firms from above rank order are grouped together to form a portfolio. Since the same study period is used to perform the grouping and cross-sectional regressions, there is a possibility of potential selection bias (Mandelkar and Rhee, 1984). To correct potential selection bias, the beta values which are significantly correlated (see Table 2) with the two independent variables (DOL and DFL) are used as the basis of ranking to form portfolios. In the study of Mandelkar and Rhee (1984) the explanatory power $\left(\mathrm{R}^{2}\right)$ of the regression model increases at the portfolio level of the firms. Therefore, the stated hypothesis is to be investigated further at the portfolio level of the firms in anticipation of increased explanatory power $\left(\mathrm{R}^{2}\right)$ of the regression model.

The next section will describe about the collection of data and estimation of dependent and independent variables and the regression models to find empirical results of this study.

\section{Empirical Test Design}

The Prowess database created by the Center for Monitoring Indian Economy (CMIE) is used to collect the data of required variables of the 10 Financial Years from 2002-2011 of 231 NSE listed manufacturing firms. The study of Sarkar, Sarkar and Sen, (2008) reports that CMIE Prowess database has become the basis of several published empirical studies on the Indian corporate sector (e.g., Khanna \& Palepu, 1999; Sarkar \& Sarkar, 2000; Bertrand, Mehta \& Mullainathan, 2002). The Financial Year from April 1 to March 31 of the following 
year is considered in India (Sarkar, Sarkar \& Sen, 2008). Total sample of 231 firms for this study is distributed across nine industries (Chemical, Diversified, Machinery, Food \& Beverage, Textiles, Transport Equipments, Non-metallic Mineral Products, Metal \& Metal Products and Miscellaneous) by the CMIE Prowess database. The NSE listed manufacturing firms with the values of required accounting variables (Annual Sales, Net Operating Profit after Tax, PE ratio, Fixed Assets, Total Debt, Total Assets, Stock Prices and Earnings per Share) as on March 31 every year from 2002 to 2011 have been extracted from CMIE Prowess database for estimating the dependent variable (PE ratio), the independent variables (DOL and DFL) and the control variables (ROA and Firm size). Finally, the complete set of data of 231 manufacturing firms distributed over nine industries has been taken to find the results.

To test the proposed Hypothesis, a Model 1 is formulated to empirically examine the joint impact of DOL and DFL on the PE ratio for the sample of 231 listed manufacturing firms. The control variables, return on assets (ROA) and firm size, are also taken to form Model 2 for examining the association of control variables with firm value. We choose the point-to-point approach (Ferri \& Jones, 1979; Mandelker \& Rhee, 1984; Garcia \& Jorgensen, 2010) to measure book DOL and book DFL. Therefore, the ten year average ratio of fixed assets to total assets is used to estimate the book DOL, and the book DFL is the ten year average ratio of total debt to total assets [3]. Similarly, the ten year average of annual sales and the ten year average ratio of Net operating profit after tax (NOPAT) to total assets (TA) are used to measure firm size (logarithm of average Sales) and ROA of each firm, respectively. Additionally, the 10-year average ratio of price-earnings (PE) of each firm is included in the study to run these cross-sectional regression models.

Model 1: $\quad \ln (P E)_{i}=\omega_{0}+\omega_{1}(D O L)_{i}+\omega_{2}(D F L)_{i}+\epsilon_{i} \quad(i=1-231)$

Where, PE, DOL and DFL are price-earnings ratio, degree of Operating leverage and degree of financial leverage, respectively.

Model 2: $\ln (P E)_{i}=\lambda_{0}+\lambda_{1}(D O L)_{i}+\lambda_{2}(D F L)_{i}+\lambda_{3} \ln (\text { Sales })_{i}+\lambda_{4}(R O A)_{i}+\phi_{i}$ $(i=1-231)$

Where, PE, DOL, DFL are Price-earnings ratio, Degree of Operating leverage, Degree of financial leverage, respectively. ROA (Return on assets) $=$ NOPAT / TA. Firm Size $=$ $\ln ($ Sales).

To further examining the Model 1 we also use a portfolio-grouping procedures (Beaver et al. 1970; Black et al. 1972; Fama \& MacBeth, 1973) employed by Mandelkar and Rhee (1984) to reduce the errors-in-variables bias. Under this approach, the average values of PE, DOL and DFL of total 231 sample firms are ranked in ascending order on the basis of ten year average value of Beta of each firm and every three firms [4] from above rank order are grouped together to form a portfolio. This means the first three firms form portfolio 1, the next three firms form portfolio 2 and so on. Thus, a total of 77 portfolios are formed for 231 


\section{Macrothink}

firms and the regression Model 3 is to be performed for finding the empirical results. To have the optimum number of portfolios in the regression Model 3, three firms in each portfolio have been considered. The portfolio of four firms (Huffman, 1989) and five firms (Mandelkar and Rhee, 1984) could also be considered.

Model 3: $\ln (P E)_{p}=\mu_{0}+\mu_{1} \quad D O L_{p}+\mu_{2} \quad D F L_{p}+\partial_{p}, \quad(p=1-77)$

Where, $P E_{p}, \mathrm{DOL}_{p}$ and $\mathrm{DFL}_{p}$ are the portfolio (p) means of eachportfolio respectively. $\partial_{p}$ is the error term.

\section{Results and Analysis}

Under this section, we present results and discuss the findings by tabulating Table 1, Table 2 and Table 3. Table 1 presents comparison of means of PE ratio, DOL, DFL, ROA, Sales and Beta for 231 sample firms distributed over nine industries. Table 2 depicts the correlations among the variables under study. Finally, Table 3 presents the results of the proposed hypotheses formulated in regression models (Model 1, 2 \& 3).

We assign the codes from one to nine to the total sample of 231 firms distributed over nine industries. Table 1 presents comparison of means of PE ratio, DOL, DFL, ROA, Sales and Beta across nine industries. The findings from the results of Table 1 indicate that there are significant differences among group means of DOL, DFL, ROA, Sales and Beta across industries. This means there is a significant variation in the values of accounting variables across industries. However, an insignificant difference among group means of PE ratio across industries is found. This suggests that industry-wise PE ratio does not vary with the variation in any of accounting variables under study. 
Table 1. Comparison of Means across Nine Industries

\begin{tabular}{|c|c|c|c|c|c|c|}
\hline & & $\begin{array}{c}\text { Sum of } \\
\text { Squares }\end{array}$ & $\begin{array}{l}\text { Degree of } \\
\text { freedom } \\
\text { (df) }\end{array}$ & $\begin{array}{c}\text { Mean } \\
\text { Square }\end{array}$ & F-Statistic & Sig. \\
\hline PE ratio & $\begin{array}{l}\text { Between Groups } \\
\text { Within Groups } \\
\text { Total }\end{array}$ & $\begin{array}{c}3.854 \\
109.932 \\
113.786\end{array}$ & $\begin{array}{c}8 \\
222 \\
230\end{array}$ & $\begin{array}{l}.482 \\
.495\end{array}$ & 0.973 & .458 \\
\hline DOL & $\begin{array}{l}\text { Between Groups } \\
\text { Within Groups } \\
\text { Total }\end{array}$ & $\begin{array}{l}0.584 \\
4.645 \\
5.229 \\
\end{array}$ & $\begin{array}{c}8 \\
222 \\
230 \\
\end{array}$ & $\begin{array}{l}.073 \\
.021\end{array}$ & 3.486 & $.001 *$ \\
\hline DFL & $\begin{array}{l}\text { Between Groups } \\
\text { Within Groups } \\
\text { Total }\end{array}$ & $\begin{array}{l}0.534 \\
6.603 \\
7.137 \\
\end{array}$ & $\begin{array}{c}8 \\
222 \\
230 \\
\end{array}$ & $\begin{array}{l}.067 \\
.030\end{array}$ & 2.243 & $.025 * *$ \\
\hline Sales & $\begin{array}{l}\text { Between Groups } \\
\text { Within Groups } \\
\text { Total }\end{array}$ & $\begin{array}{c}28.246 \\
435.692 \\
463.939 \\
\end{array}$ & $\begin{array}{c}8 \\
222 \\
230 \\
\end{array}$ & $\begin{array}{l}3.531 \\
1.963\end{array}$ & 1.799 & $.078 * * *$ \\
\hline ROA & $\begin{array}{l}\text { Between Groups } \\
\text { Within Groups } \\
\text { Total }\end{array}$ & $\begin{array}{l}0.477 \\
1.253 \\
1.730 \\
\end{array}$ & $\begin{array}{c}8 \\
222 \\
230 \\
\end{array}$ & $\begin{array}{l}.060 \\
.006\end{array}$ & 10.566 & $.000 *$ \\
\hline Beta & $\begin{array}{l}\text { Between Groups } \\
\text { Within Groups } \\
\text { Total }\end{array}$ & $\begin{array}{c}1.160 \\
11.501 \\
12.661\end{array}$ & $\begin{array}{c}8 \\
222 \\
230\end{array}$ & $\begin{array}{l}.145 \\
.052\end{array}$ & 2.798 & $.006^{*}$ \\
\hline
\end{tabular}

* significance levels at the 01 per cent; $* *$ significance levels at the 05 per cent, ${ }^{* * *}$ significance levels at the 10 per cent.

The correlation matrix is presented in Table 2 for the variables under study. In Table 2, there is significant negative correlation between $\log$ of PE and DOL and log of PE and DFL. This means degrees of operating and financial leverage adversely affect the PE ratio. No significant correlation is found between $\log$ of PE and ROA. However, there is a significant positive correlation between log of PE and firm size (log of sales). Therefore, it is expected that size of the firm could impact the price-earnings ratio but it may not be affected by ROA. This indicates the price-earnings ratio of firms operating in manufacturing sector in India could significantly be captured by DOL, DFL and firm size. Moreover, a significant positive correlation is found between DOL and DFL, the independent variables. Thus, any increased (decreased) investments in fixed assets can also increase (decrease) the total debt of the firms since we measure DOL (the ten year average ratio of net fixed assets to total assets) and DFL (the ten year average ratio of total debt to total assets). However, the problem of multicollinearity [5] does not seem to exist even though independent variables (DOL and DFL) are highly correlated. The beta values of the firms are also significantly correlated with DOL and DFL. Thus, the portfolio regression Model 3, formed on the basis of beta values, is expected to improve its explanatory power as compared to regression Model 1 and Model 2. 
Table 2. Correlation (Pearson) matrix

\begin{tabular}{|c|l|l|l|l|l|l|}
\hline & $\ln (\mathrm{PE})$ & DOL & DFL & $\ln ($ Sales $)$ & ROA & Beta \\
\hline $\ln (\mathrm{PE})$ & 1.000 & $-0.213^{*}$ & $-0.188^{*}$ & $0.117^{* *}$ & -0.007 & -0.078 \\
\hline $\mathrm{DOL}$ & & 1.000 & $0.488^{*}$ & 0.024 & 0.088 & $0.155^{*}$ \\
\hline $\mathrm{DFL}$ & & & 1.000 & -0.071 & -0.084 & $0.282^{*}$ \\
\hline $\ln ($ Sales $)$ & & & & 1.000 & 0.033 & $0.219^{*}$ \\
\hline ROA & & & & & 1.000 & $-0.153^{*}$ \\
\hline Beta & & & & & & 1.000 \\
\hline
\end{tabular}

* significance levels at the 01 per cent; $* *$ significance levels at the 05 per cent, $* * *$ significance levels at the 10 per cent.

in Table 3, the cross-section regression models run for 231 firms estimate the regression coefficients ( $\mathrm{t}$-statistic) for the predicted variable (PE ratio). The regression coefficient (positive or negative) signs are predicted for the relationship between a predicted variable (PE ratio) and each explanatory variable (DOL, DFL, ROA and Firm Size) based upon the correlations among variables under study as presented in Table 2. All models are found statistically fit on the basis of the values of F-statistic and Prob(F-statistic) presented in Table 3 (Model 1: 6.582, $\mathrm{p}<1 \%$; Model 2: 3.973, $\mathrm{p}<1 \%$; Model 3: 2.773, $\mathrm{p}<10 \%$ ). The Model 1 indicates that DOL has a statistically significant $(\mathrm{p}<.05,-0.739)$ negative association with PE ratio. However, insignificant ( $\mathrm{p}>.10,-0.444)$ negative association is found between DFL and $\mathrm{PE}$ ratio. Thus, DOL has a significant impact on the firm value but DFL does not impact the firm value. Further, the results of Model 2 shows that the control variables, ROA and firm size, have a statistically insignificant association with the PE ratio. This means that DFL, ROA and firm size have no impact on the firm value. However, a statistically significant negative $(p<.05,-.741)$ impact of DOL on the firm value in Model 2 support the results of Model 1. In order to further check the robustness of Model 1 and Model 2, a portfolio-grouping approach is adopted and 77 portfolios (three firms in a portfolio for 231 firms) are formed in ascending order based upon the beta values of 231 sample firms in Model 3. The results of Model 3 indicates the consistency in the results, significant association between DOL and firm value and insignificant association between DFL and firm value, found in Model 1 and Model 2. Besides, as expected the explanatory power of Model 3 $\left(\mathrm{R}^{2}=7 \%\right)$ is slightly higher than the Model 1 and Model 2. However, the expected results are not found if portfolios are formed on the basis of four firms and five firms for 232 firms (58 portfolios of four firms each) and 230 firms (46 portfolios of five firms each), respectively. It happens due to less number of portfolios in regression Model 3. Thus, the findings partially support our empirical investigation that DOL impacts firm value; thereby DOL is valued by 
the investors at the levels of individual firm and portfolio of firms. Since DFL has no impact on firm value, therefore this shows that firm value is independent of the capital structure (portion of total debt in total assets) of the firms which is consistent with the MM hypothesis that "The market value of any firm is independent of its capital structure" (Modigliani and Miller, 1958).

Table 3. Results from regression models

$$
\begin{aligned}
& \text { Model 1: } \ln (P E)_{i}=\omega_{0}+\omega_{1}(D O L)_{i}+\omega_{2}(D F L)_{i}+\epsilon_{i}, \quad(i=1-231) \\
& \text { Model 2: } \ln (P E)_{i}=\lambda_{0}+\lambda_{1}(D O L)_{i}+\lambda_{2} \quad(D F L)_{i}+\lambda_{3} \ln (\text { Sales })_{i}+\lambda_{4} \quad(R O A)_{i} \\
& +\phi_{i} \\
& (i=1-231)
\end{aligned}
$$

\begin{tabular}{|c|c|c|c|c|}
\hline Variable & Predicted Sign & Model 1 & Model 2 & Model 3 \\
\hline Intercept & & $\begin{array}{l}2.845^{*} \\
(24.557)\end{array}$ & $\begin{array}{l}2.365 * \\
(7.397)\end{array}$ & $\begin{array}{c}3.144^{*} \\
(13.416)\end{array}$ \\
\hline DOL & -- & $\begin{array}{l}-0.739 * * \\
(-2.146) \\
\end{array}$ & $\begin{array}{c}-0.741 * * \\
(-2.133) \\
\end{array}$ & $\begin{array}{r}-1.524 * * \\
(-2.084)\end{array}$ \\
\hline DFL & -- & $\begin{array}{l}-0.444 \\
(-1.506)\end{array}$ & $\begin{array}{c}-0.414 \\
(-1.391)\end{array}$ & $\begin{array}{c}0.010 \\
(0.017)\end{array}$ \\
\hline $\ln ($ Sales $)$ & + & & $\begin{array}{c}0.052 \\
(1.639) \\
\end{array}$ & \\
\hline $\mathrm{ROA}$ & -- & & $\begin{array}{c}-0.043 \\
(-0.081) \\
\end{array}$ & \\
\hline $\mathrm{R}^{2}$ & & 0.055 & 0.066 & 0.070 \\
\hline F-statistic & & 6.582 & 3.973 & 2.773 \\
\hline Prob(F-statistic) & & 0.002 & 0.004 & 0.069 \\
\hline Sample firms & & 231 & 231 & 231 \\
\hline
\end{tabular}$$
\text { Model 3: } \ln (P E)_{p}=\mu_{0}+\mu_{1} \quad D O L_{p}+\mu_{2} \quad D F L_{p}+\partial_{p}, \quad(p=1-77)
$$$$
\text { Dependent Variable: PE ratio }
$$$$
\begin{array}{|c|c} 
& \\
\cline { 2 - 2 } & \text { Coefficient Estimate (t-statistic) }
\end{array}
$$

* significance levels at the 01 percent; ** significance levels at the 05 per cent, $* * *$ significance levels at the 10 per cent. Figures in parentheses are t-values. 


\section{Conclusion}

The empirical results and discussion of this study partially support the hypothesis that DOL and DFL do impact the firm value. DOL does significantly adversely affects the firm value over long windows; however DFL and firm value are not associated. Interestingly, both DOL and DFL are significantly negatively correlated with the firm value (see Table 2). Moreover, controlling for firm size and ROA does not affect the results of the study and both control variables do not explain the firm value. Our findings remain intact even after a well established portfolio-grouping approach is used to find the empirical results of the study. Thus, investors consider DOL an important accounting number in valuing the firms at marketplace. Our empirical results also indicate that firm value is independent of its capital structure (portion of total debt in total assets) as DFL does not impact firm value. No significant difference in PE ratio, proxy of firm value, of 231 sample firms distributed over nine industries is found though they are significantly different in terms of size (annual sales), profitability (ROA) and degree of leverages (see Table 1). This study is an addition to the literature of Capital market-based accounting research (CMBAR) which studies the association between stock price-based dependent variable and accounting variables in Indian context. The association between degree of leverages and stock risk and returns could be explored in the context of emerging or developing markets. Besides, the same study could be revisited in the context of under-developed markets to reexamine the reliability in the findings of this study.

\section{End Notes}

[1] Logarithm transformation for symmetrical and normal distribution of data.

[2] The market model approach (Mandelkar and Rhee, 1984) is used to estimate the beta values of each firm's common stock with 10 years of monthly data.

$$
R_{i t}=\alpha_{i}+\beta_{i} R_{m t}+u_{i t} \quad i=1-231, t=1-120
$$

Where, $\mathrm{R}_{\mathrm{i}}$ and $\mathrm{R}_{\mathrm{m}}=$ The monthly rates of return in month $\mathrm{t}$ on a common stock and an Market Index (NSE Nifty 50);

$\alpha_{i}, \beta_{i}=$ The intercept and slope coefficient representing the Beta Values, respectively.

[3] Note that Garcia and Jorgensen (2010) use the five-year average ratio of fixed assets to total assets is used to estimate the book DOL, and the Book DFL is the five-year average ratio of total debt divided by total assets. Mandelker and Rhee (1984) use these two ratios, ratio of fixed assets to total assets and ratio of total debt to total assets, as the instrumental variables for DOL and DFL, respectively.

[4] Note that Huffman (1989) and Mandelkar and Rhee (1984) were used portfolio of four stocks and five stocks, respectively.

[5] Based upon the values of Variation inflation factor (VIF) in each Model. 


\section{References}

Alford, A. W. (1992). The Effect of the Set of Comparable Firms on the Accuracy of Price-Earnings Valuation Method. Journal of Accounting Research, 30(1), 94-108. http://dx.doi.org/10.2307/2491093

Al-Khazali, O. M., \& Zoubi, T. A. (2005). Empirical Testing of Different Alternative Proxy Measures for Firm Size. The Journal of Applied Business Research, 21(3), 79-90.

Anderson, K., \& Brooks, C. (2006). Decomposing the Price-Earnings Ratio. Journal of Asset Management, 6(6), 456-469. http://dx.doi.org/10.1057/palgrave.jam.2240195

Ang, J. \& Peterson, P.P. (1984). The Leasing Puzzle. Journal of Finance, 39(4), 1055-1065. http://dx.doi.org/10.1111/j.1540-6261.1984.tb03892.x

Azmat, Qurat-ul-ann. (2014). Firm value and optimal cash level: evidence from Pakistan. International Journal of Emerging Markets, 9(4), 488-504. http://dx.doi.org/10.1108/IJoEM-11-2011-0104

Ball, R., \& Brown, P. (1968). An empirical evaluation of accounting income numbers. Journal of Accounting Research, 6(2), 159-178. http://dx.doi.org/10.2307/2490232

Barth, M. E., Beaver, W. H., \& Landsman, W. R. (2001). The relevance of the value relevance literature for financial accounting standard setting: Another view. Journal of Accounting and Economics, 31, 77-104. http://dx.doi.org/10.1016/S0165-4101(01)00019-2

Beaver, W., Kettler, P., \& Scholes, M. (1970). The association between market-determined and accounting determined risk measures. The Accounting Review, 45(4), $654-682$.

Beaver, W., \& Morse, D. (1978). What Determines Price-Earnings Ratios. Financial Analysts Journal, 34 (4), 65-76. http://dx.doi.org/10.2469/faj.v34.n4.65

Beisland, L.A. (2009). The review of the value relevance literature. The Open Business Journal, 2, 7-27. http://dx.doi.org/10.2174/1874915100902010007

Bekaert, G., \& Harvey, C.R. (2013). Emerging Equity Markets in a Globalizing World. Working Paper. http://dx.doi.org/10.2139/ssrn.2344817

Bertrand, M., Mehta, P., \& Mullainathan, S. (2002). Ferreting out tunneling: an application to Indian business groups. Quarterly Journal of Economics, 117(1), 121-148. http://dx.doi.org/10.1162/003355302753399463

Bhadu, S. K., \& Warne, D. P. (2009). Parametric Determinants of Price-Earnings Ratio in Indian Capital Markets. The IUP Journal of Applied Finance, 15(9), 63-82.Retrieved from http://ssrn.com/abstract=1470591

Bhandari, L.C. (1988). Debt/equity ratio and expected common stock returns: empirical evidence. Journal of Finance, 43(2), 507-528. http://dx.doi.org/10.1111/j.1540-6261.1988.tb03952.x 
Bianchi, Constanza. (2014). Internationalisation of emerging market firms: an exploratory study of Chilean companies. International Journal of Emerging Markets, 9(1), 54-78. http://dx.doi.org/10.1108/IJoEM-02-2010-0013

Black, Fischer. (1972). Capital Market Equilibrium with Restricted Borrowing. Journal of Business, 45(3), 444-455. http://dx.doi.org/10.1086/295472

Black, F., Jensen, M. C., and Scholes, M. (1972). The Capital Asset Pricing Model: Some Empirical Tests. In Jensen, M. C., Studies in the Theory of Capital Markets. New York: Ptaeger.

Capital Markets in 2025: The future equity capital markets. A PwC IPO Centre Publication, Retrieve from http://www.pwc.de/de_DE/de/kapitalmarktorientierte-unternehmen/assets/Capital_Markets_i n_2025_web.pdf (accessed 25 July 2015).

Carlson, M., Fisher, A., \& Giammarino, R. (2004). Corporate Investment and Asset Price Dynamics: Implications for the Cross Section of Returns. Journal of Finance, 59(6), 2577-2603. http://dx.doi.org/10.1111/j.1540-6261.2004.00709.x

Cheng, Ming-Chang \& Tzeng, Zuwei-Ching (2011). The Effect of Leverage on Firm Value and How the Firm Financial Quality Influence on This Effect. World Journal of Management, $3(2), 30-53$.

Cheung, W.Y., \& Ng, L.K. (1992). Intersections Between the U.S. and Japan stock market Indices. Journal of International Financial Management, Institutions and Markets, 21(1), 93-108.

Christie, A.A. (1982). The stochastic behaviour of common stock variance value, leverage and interest rate effects. Journal of Financial Economics, 10(4), 407-32. http://dx.doi.org/10.1016/0304-405X(82)90018-6

Collins, D., Rozeff, M., \& Dhaliwal, D. (1981). The Economics Determinants of the Market Reaction to Proposed Mandatory Accounting Changes in the Oil and Gas Industry: A Cross-Sectional Analysis. Journal of Accounting and Economics, 3(1), 37-71.

Cooper, I. (2006). Asset pricing implications of non-convex adjustment costs and irreversibility of investment. Journal of Finance, 61(1), 139-170. http://dx.doi.org/10.1111/j.1540-6261.2006.00832.x

Deakin, E. (1979). An Analysis of Differences between Non-Major Oil Firms Using Successful Efforts and Full Cost Methods. Accounting Review, 54(4), 722-734.

DeYoung, R., \& Roland, K.P. (2001). Product Mix and Earnings Volatility at Commercial Banks: Evidence from a Degree of Total Leverage Model. Journal of Financial Intermediation, 10, 54-84. http://dx.doi.org/10.1006/jfin.2000.0305 
Dimitrov, V., \& Jain, P.C. (2008). The value relevance of changes in financial leverage beyond growth in assets and GAAP earnings. Journal of Accounting, Auditing \& Finance, 23 (2), 191-222.

Dotan, A., \& Ravid, S.A. (1985). On the Interaction of Real and Financial Decisions of the Firm under Uncertainty. Journal of Finance, 40, 501-517. http://dx.doi.org/10.1111/j.1540-6261.1985.tb04969.x

Dumontier, P., \& Raffournier, B. (2002). Accounting and capital markets: a survey of the European evidence. The European Accounting Review, 11(1), 119-151. http://dx.doi.org/10.1080/09638180220124761

Fama, E. F., \& Macbeth, J. D. (1973). Risk, Return, and Equilibrium: Empirical Tests. Journal of Political Economy, 81, 607-636. http://dx.doi.org/10.1086/260061

Ferri, M. G., \& Jones, W.H. (1979). Determinants of Financial Structure: A New Methodological Approach. Journal of Finance, 34(3), 631-644. http://dx.doi.org/10.1111/j.1540-6261.1979.tb02130.x

Flatt, S.J., \& Kowalczyk, S.J. (2008). Creating competitive advantage through intangible assets: the direct and indirect effects of corporate culture and reputation. Advances in Competitiveness Research, 16(1-2), 1188-1211.

Francis, J., \& Schipper, K. (1999). Have financial statements lost their relevance? Journal of Accounting Research, 37(2), 319-352. http://dx.doi.org/10.2307/2491412

French, K.R., Schwert, G.W., \& Stambaugh, R.F. (1987). Expected stock returns and volatility. Journal of Financial Economics, 19(1), 3-29. http://dx.doi.org/10.1016/0304-405X(87)90026-2

Gahlon, J.M., \& Gentry, J.A. (1982). On the relationship between systematic risk and the degrees of operating and financial leverage. Financial Management, 11(2), 15-23. http://dx.doi.org/10.2307/3665021

Garcia-Feijoo, L., \& Jorgensen, R.D. (2010). Can operating leverage be the cause of the value premium? Financial Management, 39(3), 1127-1153. http://dx.doi.org/10.1111/j.1755-053X.2010.01106.x

Garten, J.E. (1997). Who are the big emerging markets, and why are they important? In Garten, J.E. (Ed.), The Big Ten: The Big Emerging Markets and How They Will Change Our Lives (pp.3-23). New York: HarperCollins.

Griffin, H.F., \& Dugan, M.T. (2003). Systematic Risk and Revenue Volatility. Journal of Financial Research, 26, 179-189. http://dx.doi.org/10.1111/1475-6803.00053

Graham, B., \& Dodd, David (1934). Security Analysis. New York: Mcgraw- Hill.

Habib, A. (2004). Impact of earnings management on value-relevance of accounting information: empirical evidence from Japan. Managerial Finance, 30(11), 1-15. http://dx.doi.org/10.1108/03074350410769344 
Habib, Ahsan (2010). Value relevance of alternative accounting performance measures: Australian evidence. Accounting Research Journal, 2 (2), 190-212. http://dx.doi.org/10.1108/10309611011073269

Habib, Ahsan \& Azim, Istiaq (2008). Corporate governance and the value-relevance of accounting information: Evidence from Australia. Accounting Research Journal, 21(2), 167 194. http://dx.doi.org/10.1108/10309610810905944

Ho, Y.K., Xu, Z., \& Yap, C.M. (2004). R\&D Investment and Systematic Risk. Accounting and Finance, 44, 393-418. http://dx.doi.org/10.1111/j.1467-629x.2004.00116.x

Holthausen, R.W., \& Watts, R.L. (2001). The relevance of the value-relevance literature for financial accounting standard setting. Journal of Accounting and Economics, 31(1-3), 3-75. http://dx.doi.org/10.1016/S0165-4101(01)00029-5

Hoskisson, R.E., Eden, L., Lau, C.M., \& Wright, M. (2000). Strategy in emerging economies. Academy of Management Journal, 43(3), 249-267. http://dx.doi.org/10.2307/1556394

Huffman, L. (1983). Operating Leverage, Financial Leverage, and Equity Risk. Journal of Banking and Finance, 7, 197-212. http://dx.doi.org/10.1016/0378-4266(83)90032-8

Huffman, Stephen P. (1989). The Impact of the Degree of Operating and Financial leverage on the Systematic Risk of Common Stocks: Another look. Quarterly Journal of Business and Economics, 28(1), 83-100.

Hughes, J., \& Ricks, W. (1984). Accounting for Retail Land Sales: Analysis of a Mandated Change. Journal of Accounting and Economics, 6(1), 101-132. http://dx.doi.org/10.1016/0165-4101(84)90009-0

International Equity Markets. Chapter IX, Retrieve from http://www.bauer.uh.edu/rsusmel/7386/ln9.pdf (accessed 25 July 2015).

Jensen, M., \& MeCkling, W. (1978). Can the Corporation Survive? Financial Analyst Journal, 34(1), 31-37. http://dx.doi.org/10.2469/faj.v34.n1.31

Kale, J.R., Noe, T.H., \& Ramirez, G.G. (1991). The Effect of Business Risk on Corporate Capital Structure: Theory and Evidence. Journal of Finance, 46, 1693-1715. http://dx.doi.org/10.1111/j.1540-6261.1991.tb04640.x

Khanna, T., \& Palepu, K. (1999). Emerging Market Business Groups, Foreign Investors and Corporate Governance. NBER Working Paper Series, Working Paper 6955. http://www.nber.org/papers/w6955.pdf

Lee, N., \& Swenson, C. (2012). Are multinational corporate tax rules as important as tax rates? The International Journal of Accounting, 47(2), 155-167. http://dx.doi.org/10.1016/j.intacc.2012.03.001

Lie, E., \& Lie, H.J. (2002). Multiples Used to Estimate Corporate Value. Financial Analysts Journal, 58(2), 44-54. http://dx.doi.org/10.2469/faj.v58.n2.2522 
Mandelker, G.N., \& Rhee, S.G. (1984). The impact of the degrees of operating and financial leverage on systematic risk of common stock. Journal of Financial and Quantitative Analysis, 19(1), 45-57. http://dx.doi.org/10.4337/9781781009147.00028

Merchant, H., \& Allen-Ford, L. (2012). Management research on emerging markets: existing trends and future opportunities. In Verbeke, A. and Merchant, H. (Eds.), Handbook of Research on International Strategic Management (pp.363-387). London, UK: Edward Elgar Publishing.

Modigliani, Franco \& Miller, Merton H. (1958). The Cost of Capital, Corporation Finance and the Theory of Investment. The American Economic Review, 48(3), 261-297.

Nishat, M. (2000). The systematic risk and leverage effect in the corporate sector of Pakistan.

The Pakistan Development Review, 39(4), 951-962.

Papadaki, P., \& Siougle, G. (2007). Value relevance of price, earnings and book values in the Athens stock exchange. Managerial Finance, 33(5), 309-320. http://dx.doi.org/10.1108/03074350710739597

Pari, R., Carvell, S., \& Sullivan, T. (1989). Analyst forecasts and price-earnings ratios. http://dx.doi.org/10.2469/faj.v45.n2.60

Prezas, A. P. (1987). Effects of Debt on the Degrees of Operating and Financial Leverage. Financial Management, 16(2), 39-44. monetary policies on the performance of the Nigerian manufacturing companies during the period 1986-2012

Sarkar, J., \& Sarkar, S. (2000). Large shareholder activism in corporate governance in developing countries: evidence from India. International Review of Finance, 1(3), 161-194. http://dx.doi.org/10.1111/1468-2443.00010

Sarkar, J., Sarkar, S., \& Sen, K. (2008). Board of directors and opportunistic earnings management: evidence from India. Journal of Accounting, Auditing and Finance, 23(4),

517-551. http://dx.doi.org/10.1177/0148558X0802300405

Sarma, L. V. L. N., \& Rao, K. S. H. (1969). Leverage and the Value of the Firm. The Journal of Finance, 24(4), 673-677. http://dx.doi.org/10.1111/j.1540-6261.1969.tb00391.x

Schwert, William. (1989). Why Does Stock Market Volatility Change over Time? Journal of Finance, 44, 1115-1153. http://dx.doi.org/10.1111/j.1540-6261.1989.tb02647.x

Sharma, A.K. (2006). Financial leverage and firms' value: a study of capital structure of selected manufacturing sector firms in India. The Business Review, Cambridge. 6(2), 70-76.

Shehata, M. (1991). Self-Selection Bias and the Economic Consequences of Accounting Regulation: An Application of a Two-Stage Switching Regression to SFAS No. 2. The Accounting Review, 66(4), 768-787.

Stefanis, Lambros (2005). Testing the Relation between Price-to-Earnings Ratio and Stock Returns in the Athens Stock Exchange. http://dx.doi.org/10.2139/ssrn.872272 
Trabelsi, J.E. (2013). The value relevance of earnings and cash flows: the Tunisian stock market evidence. International Journal Accounting and Finance, 4(1), 98-117. http://dx.doi.org/10.1504/IJAF.2013.053115

Trezevant, R. (1992). Debt Financing and Tax Status: Tests of the Substitution Effect and the Tax Exhaustion Hypothesis Using Firms' Responses to the Economic Recovery Tax Act of 1981. Journal of Finance, 47, 1557-1568. http://dx.doi.org/10.1111/j.1540-6261.1992.tb04670.x

Zadeh, F.O., \& Eskandari, A. (2012). Firm Size As Company's Characteristic and Level of Risk Disclosure: Review on Theories and Literatures. International Journal of Business and Social Science, 3 (17) 9-17.

Zhang, L. (2005). The Value Premium. Journal of Finance, 60(1), 67-103. http://dx.doi.org/10.1111/j.1540-6261.2005.00725.x

Zimmer, S.A. (1990). Event risk premia and bond market incentives for corporate leverage. FRB New York Quarterly Review, 15(1),15-30.

Zimmerman, J. (1983). Taxes and Firm Size. Journal of Accounting and Economics, 5(1), 119-149. http://dx.doi.org/10.1016/0165-4101(83)90008-3

Zmijewski, M., \& Hagerman, R. (1981). An Income Strategy to the Positive Theory of Accounting Standard Setting Choice. Journal of Accounting and Economics, 3(1), 129-149. http://dx.doi.org/10.1016/0165-4101(81)90010-0 